\title{
Memories of madness: the County of Lancaster Asylum, Rainhill, 1890
}

\author{
Richard C. Barnes
}

\begin{abstract}
An account of the thoughts of a fictional Assistant Medical Officer (AMO) on duty at the County of Lancaster Asylum, Rainhill in 1890 is given. If is based on the contemporary case records and other literary sources and is as factually accurate as possible. However, any similartly to persons living or dead is coincidental and unintentional.
\end{abstract}

The Assistant Medical Officer (AMO) slumped into his battered old armchair. His customary last tour of the wards completed, he had indulged himself by 'borrowing' a small bottle of brandy from the medicine chest on ward 10. The attendants on 10 would never notice. That maddest of wards in the madhouse would keep them busy enough even tonight. Even tonight, the last day of December 1890. And what a place to see the New Year in; alone in a tiny room in Main House, duty AMO for Rainhill Hospital.

As he sat, he pondered over what 1890 had brought him in the way of work. Only an average year, yet almost daily he had sat with the duty Medical Officer and had seen admitted 641 patients (Parker et al, 1993) recorded in one of the four great leather-bound case-books.

He had watched his superiors etch their marks indeliby onto the folio sheets. Dr Atwood-Beaver in his looping, almost flamboyant hand which always proved so hard to read. Dr Menzies, who wrote smaller, more neatly and recording such detail of their neurology he must surely have a special interest there. Or Dr Wiglesworth, the Medical Superintendent. Always writing in almost perfect copperplate, always concise and to the point. A locally trained man who must be only a year or so from being elected a Fellow of the Royal College of Physicians (and, though the AMO could not have known, only four years from receiving a near fatal stab wound in the back from one of his charges (Regan, 1986)).

Only an average year, but he had seen some interesting cases.
That poor, wretched melancholic whose lowering of mood had reached such a point she had become insane. Her notes had recorded that on admission she was "in a very depressed condition.... and says she has no throat, no tongue, no stomach, no intestines and no passage and that she cannot eat any food. She holds her tongue because she is frightened it will fall back and choke her. Only speaks in a whisper. Has much anaesthesia and a pin can be stuck through her nasal cartilage, ear and tongue with hardly any pain". Vaguely he recalled reading somewhere of a recent description of a similar patient by the Frenchman Cotard. Perhaps Dr Wiglesworth would recall the journal (Cotard, 1882).

Other patients had been much happier though. The young maniac girl who had so irritated Dr Menzies, prompting him to record she was "in a condition of considerable exaltation. She is chatty, merry and decidedly 'cheeky'. Answers back and tries to be witty and make jokes which are often inappropriate and poor but amuse her very much".

Livelier still had been the man who had greeted him like a long-lost brother and was "jovial and exalted, smiling continually and making personal comments all round". How rapidly his Irish tongue had gabbled that he was "guided by three colours, blue which means true, white is alright so I will be alright if I am the best man, as I will wear a white collar, and green which is Ireland. The trees outside are green so this is Ireland".

And what of the lunatic whom Dr AtwoodBeaver had described using Morel's term, dementia praecox (Morel, 1860). Her mental state had recorded that "she rambles off into a longwinded and incoherent tale having no apparent connection with the current question but quite full of expressions of pious joy and thankfulness. Questions set to clarify her points only make the story less clear".

Thoughtfully, the AMO sipped a little more of his purely medicinal brandy. Its gentle fire 
warmed his throat as the flame in the hearth slowly toasted his shins. Alcohol raised his spirits a little, but also put him in mind of the other things it could do to a man.

The delirious patient they had admitted in summer. That man's appearance was "that of a confirmed drunkard. His whole muscular system is in a state of tremor and his speech slurred. He hears voices and sees serpents and faces on the walls. He is irritable and sleepless and his memory for recent events is gone".

Surely the occasional brandy, and cheap hospital stuff at that, could never bring a young AMO to such a state. Those problems were only for the moral defective. Certainly he would never need fear the problems wrought by that other great moral deficiency, masturbation. Who could forget the inmate who "says he has not abused himself for several weeks, though he looks like a masturbater" and the other, who "is now showing all the physical characteristics of a masturbater" and was "quite addicted to it".

There had been no need to record their distinctive physical characteristics. His trusty copy of Clouston's Mental Diseases (1889) clearly described the thin frame and pale expression, weak constitution, dilated pupils and cold extremities.

Night was drawing round him, but he attempted to fight back sleep as best he could; determined to see the New Year in before he retired. To help keep awake he tried to recall the medications he had prescribed that night. Salts of bismuth and antimony, pulverised ipecac, chloral hydrate and, of course, the faithful paraldehyde. Opium and arsenides, with brandy as a diluent if for oral consumption, or with starch for the rectal route. His enema mix of opium, dilute sulphuric acid, cardamon and brandy every two hours. The diet prescribed for his melancholic of "hot beef tea, broth, custard and pulverised fruit, beer and brandy".

Nothing worked for the idiots though. How could he forget the way they stood in the admission room as they came in.

One boy, barely 8-years-old, with "a dull, heavy expression of countenance, a hang-dog look, coarse speech, a dogged indifference to his surroundings and a total lack of ambition" combining to "stamp the boy to be an imbecile. He rarely raises his face and stands cowed before me as though thoroughly ashamed of himself".

Another, whom Dr Menzies carefully examined and noted to have a "a protruding tongue", "heavy brows", "sloping eyes" and a "vacant expression" so like the patients Langdon Down had described (Down, 1866). The mental state had been less meticulous though; "he is an idiot. Cannot speak but rambles restlessly about, masturbates freely".

But most distressing of all, the poor 7-yearold lad coming from West Derby workhouse, Dr Atwood-Beaver it had been that day, who, in somewhat poetic mood, had recorded that most memorable mental state.

"A nasty squealing child without a redeeming feature or a spark of intelligence to relieve such a disposition. He is incapable of paying any attention at all. Takes no notice of any question which requires a moment on his part to answer. He snarls and screeches when handled very much like a monkey when teased whilst eating. He is dirty in his habits and utterly indifferent to the calls of nature. He utters no sound in any way dimly reflecting articulate speech, and when asked to repeat simple monosyllables he cooly ignores what is said. He is very fond of exploring crevices in the room and picks up rubbish which is as often as not conveyed to his mouth. He is mischievous and is never out of mischief so to say. The consequence is that he is an unmitigated nuisance. His mental state is as unattractive as his physical condition, his harsh voice grating unpleasantly on the bystander's ear."

Once they were transferred to the annex he had no need to see them again. Review over there was done by the senior staff, each inmate seen once every two years (at best. He knew of cases in which the inmate had died after 23 years in the hospital with only three entries in the case-book). Case-book entries were more prosaic there, "dementia, in good health", "an idiot, works well. Physically healthy", "a useless idiot. Feeble".

It was during the long sigh that hauled itself then from deep in his chest that he heard the asylum church bell begin to toll the hour. Midnight rang out across the silent grounds in sad and sonorous tones. Only when the last echo died did he realise that he had interrupted his sigh and held his breath. He let it out and felt a wave of relaxation spread over him. Time for bed.

Soon he would be moving on, but his time at Rainhill had been happy. Rainhill was a progressive asylum, with a policy of no mechanical restraint, where $60 \%$ of the inmates were employed in some capacity (Regan, 1986). He was sure that his experiences here would be useful for his further career. 
He was equally sure that a fine asylum like Rainhill, new and well run, would provide care for the insane for many hundreds of years to come.

\section{Postscript}

The fictional AMO's last thought, though reflecting the philosophy of the time, was to prove wrong. Less than half a century after this date the movement against asylum care began.

Rainhill hospital finally closed on 27 September 1991. It now stands, decaying, in its old grounds, soon to be demolished. Its lands are to be used for office buildings.

\section{Acknowledgement}

The author would like to thank Mrs J. E. Anstiss for her helpful comments on earlier drafts.

\section{References}

CLouston, T. S. (1889) Clinical Lectures on Mental Diseases. 4th edn. London: Churchill. pp. 21-25.

COTARD. J. (1882) Archives of Neurology. 4. 152-170. 282-296.

Down, J. L. H. (1866) Observations on an ethnic classification of idiots. Clinical Lecture Reports, London Hospital. 3. 259-262.

MOREL, B. A. (1860) Tratté des Maladies Mentales. Paris: Masson.

Parker, R. R., DutTA, A., Barnes, R. C., et al (1993) The County of Lancaster Asylum Rainhill, 100 Years Ago and Now. History of Psychiatry, 4, 95-105.

REGAN. M. (1986) A Caring Society: a study of lunacy in Liverpool and South-West Lancashire from 1650 to 1948. St Helens and Knowsley Health Authority.

Richard C. Barnes, Senior Registrar in Old Age Psychiatry. Rehabilitation \& Special Care Directorate, Rathbourne Hospital, Mill Lane, Liverpool L13 4AW

\title{
GASKELL ACADEMIC SERIES
}

\section{Interpersonal Factors in Origin and Course of Affective Disorders}

\author{
Edited by $\mathrm{Ch}$. Mundt, with the assistance of Hugh Freeman
}

This detailed overview of the latest research on affective disorders brings together authors of international background and repute. Both a theoretical and practical approach to the origin and course of affective disorders is presented, covering specific problems and settings. The principal areas covered are: personality factors, risk and course; social support; marital and family interaction; and intervention.

- $£ 25.00 \bullet 396 p p . \bullet 1995 \bullet$ ISBN 1902241907

Available from bookshops and from the Publications Department, Royal College of Psychiatrists, 17 Belgrave Square, London SW1X 8PG (Tel. 0171-235 2351, extension 146)

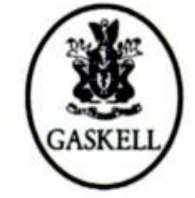

